\title{
Comment
}

\section{India - Additional and Extra-Additional Duties on Imports from the United States}

\author{
FRIEDER ROESSLER \\ Executive Director, Advisory Centre on WTO Law
}

\section{Introduction}

Under the provisions of the GATT governing import charges and internal taxes, the Members of the WTO may levy internal taxes on imported products through their customs services. The relationship between the provisions governing import charges and those governing internal taxes was addressed for the first time by a panel and the Appellate Body in India-Additional Import Duties. I do not believe that this relationship was correctly analysed by the Panel. While the commentators describe correctly the rulings of the Panel and the modifications to those rulings by the Appellate Body, they do not provide an explanation of the function and interrelationship of the various provisions on import charges and internal taxes. I would like to complement their analysis by setting out my understanding of the function and interrelationship of these provisions in Section 2 below.

In the economic section of their paper, the commentators make a number of statements regarding the WTO rules governing border tax adjustments that I consider incorrect. In Section 3 below, I present my understanding of those rules and address those inaccuracies.

\section{The relationship between the GATT provisions governing import charges and those governing internal taxes}

The basic provisions of the GATT governing customs duties and other charges imposed on the importation of products of other Members are paragraphs 1(b) and 2 of Article II. The basic rules set out in Article II:1(b) read as follows:

The products described in ... the Schedule ... shall, on their importation ... be exempt from ordinary customs duties in excess of those set forth and provided therein. Such products shall also be exempt from all other duties or charges of any kind imposed on or in connection with the importation. 
The first sentence of paragraph $1(\mathrm{~b})$ obliges WTO Members to exempt the products described in their Schedule of Concessions from ordinary customs duties in excess of those set forth in that Schedule (generally described as 'bound rates'). The second sentence obliges Members to exempt such products from 'all other duties or charges of any kind imposed on or in connection with the importation'. The two sentences of Article II:1(b) have different objectives. According to the first sentence, no customs duty may be levied that exceeds the bound rate. It is intended to protect the results of market-access negotiations. The second sentence obliges Members to reduce the number and diversity of import duties or charges by prohibiting, in principle, all duties and charges on bound items other than ordinary customs charges. It is intended to facilitate trade in bound items by simplifying customs procedures. It is thus not sufficient that the total of all duties and charges levied on or in connection with the importation of a bound item does not exceed the bound rate. Duties and charges of any kind other than ordinary customs duties are, in principle, prohibited whatever their level.

There are a number of important exceptions to the general prohibition of other duties and charges on the importation of products included in the Schedule of Concessions. The first is contained in the second sentence of Article II:1(b) itself. This provision permits other duties and charges that are not

... in excess of those imposed on the date of this Agreement or those directly and mandatorily required to be imposed thereafter by legislation in force in the importing territory on that date.

This exemption has been further elaborated in the Understanding on the Interpretation of Article II:1(b) of the GATT 1994. Paragraph 2 of the Understanding defines the 'date of this Agreement' as follows:

The date as of which 'other duties or charges' are bound, for the purposes of Article II, shall be 15 April 1994. 'Other duties or charges' shall therefore be recorded in the Schedules at the levels applying on this date.

Paragraph 7 of the Understanding provides:

'Other duties or charges' omitted from a Schedule at the time of deposit of the instrument incorporating the Schedule in question into GATT 1994 ... shall not subsequently be added to it and any 'other duty or charge' recorded at a level lower than that prevailing on the applicable date shall not be restored to that level unless such additions or changes are made within six months of the date of deposit of the instrument.

The Panel in Dominican Republic-Import and Sale of Cigarettes noted that Members were required under the above provisions of the Understanding to record all other duties and charges as applied on 15 April 1994 within six months of the date of deposit of the instrument by which they accepted the WTO Agreement and that no further duties and charges could be recorded after that point in time. 
The Panel concluded from this that Article II:1(b), second sentence read together with the Understanding meant that:

imported products shall be exempted from all 'other duties or charges' of any kinds in excess of those as validly recorded in the Schedule of the Member concerned. ${ }^{1}$

The advantage of the Understanding is that each Member's Schedule now clearly indicates not only the maximum rates of ordinary customs duties the Member may levy in accordance with the first sentence of Article II:1(b) but also all other duties and charges that the Member may impose in accordance with the second sentence of that provision.

A further exemption from the general prohibition of other duties and charges on bound items is contained in Article II:2, which reads as follows:

Nothing in this Article shall prevent [Member] from imposing at any time on the importation of any product:

(a) a charge equivalent to an internal tax imposed consistently with the provisions of paragraph 2 of Article III in respect of the like domestic product or in respect of an article from which the imported product has been manufactured or produced in whole or in part;

(b) any anti-dumping or countervailing duty applied consistently with the provisions of Article VI;

(c) fees or other charges commensurate with the cost of services rendered.

Articles III, VI, and VIII of the GATT set out the conditions under which charges equivalent to internal taxes, and anti-dumping or countervailing duties and fees for services rendered, may be levied. This raises the question of why it was necessary to provide in Article II:2 for an explicit permission to levy charges consistent with those Articles. The answer is that, while Articles III, VI, and VIII regulated the levying of specific charges, they do not permit their imposition as a condition on the importation of products. For instance, while Article VI:2 states that Members 'may levy on any dumped product an anti-dumping duty', it does not exempt antidumping duties from the general prohibition of duties and charges other than ordinary customs duties on the importation of bound items set out in Article I:1(b). Given this general prohibition, the right to levy an anti-dumping duty on dumped products must be distinguished from the right to levy such a duty as a condition of importation. Articles III, VI, and VIII can consequently not be interpreted to imply the right to burden the process of importation with the collection of the charges they regulate. That right is conferred by Article II:2.

To summarize: Articles III, VI, and VIII permit Members to impose specific charges; the function of Article II:2 is to accord them the right to levy these charges as a condition of importation notwithstanding the general prohibition to burden 
the process of importation with the levying of charges other than ordinary customs duties set out in Article II:1(b), second sentence.

In respect of charges equivalent to an internal tax, Article II: 2 has further functions. The application of internal measures is governed by the national-treatment provisions of Article III of the GATT. In respect of internal taxes, Article III:2(a) states:

The products of the territory of any [WTO Member] imported into the territory of any other [WTO Member] shall not be subject, directly or indirectly, to internal taxes or other internal charges of any kind in excess of those applied, directly or indirectly, to like domestic products.

The Note ad Article III provides in relevant part:

Any internal ... charge ... which applies to an imported product and to the like domestic product and is collected ... in the case of the imported product at the time or point of importation is nevertheless to be regarded an ... internal charge ... subject to the provisions of Article III.

This Note defines the scope of application of Article III. It makes clear that an internal charge is not turned into a 'border charge' subject to Article II:1(b) merely because it is collected in respect of imported products at the time or point of importation. However, the Note does not define the scope of Article III to comprise charges levied 'on the importation' of products equivalent to internal taxes on like products. Such charges are levied as a condition of importation - and consequently not on products already imported - and therefore fall under the general prohibition of other duties and charges set out in Article II:1(b), second sentence.

Moreover, the Note ad Article III covers only a 'charge which applies to an imported product and to the like domestic product'. It thus covers only charges on imported products that are identical to those on domestic products. However, in many instances, governments cannot apply to imported products the same charges that they apply to domestic products. For instance, a tax on domestic products that takes the form of a business turnover tax cannot be levied in that form on imported products because there is in respect of imported products no business turnover that could be the basis of taxation. To equalize conditions of competition in such a case, governments must be permitted to levy a charge upon importation that is economically equivalent but not identical to the domestic turnover tax. An additional function of Article II:2(a) thus is to exempt border charges that are not identical to internal taxes but economically equivalent to such taxes from the general prohibition of charges other than ordinary customs duties.

To summarize: an internal charge consistent with Article III may be imposed in respect of imported products 'at the time or point of importation' according to the Note ad Article III and a border charge that is equivalent to an internal tax consistent with Article III may be imposed according to Article II:2(a). WTO Members may thus use their customs services to collect their internal charges in respect of 
Table 1. Customs duties and other charges on importation: basic principles as set out in GATT Articles II:1(b), II:2(a), and III:2

\begin{tabular}{|c|c|c|}
\hline Charge & Principle & Main provisions \\
\hline Ordinary customs duties & $\begin{array}{l}\text { Permitted } \\
\text { but must not exceed } \\
\text { level of tariff binding }\end{array}$ & Article II:1(b) of the GATT \\
\hline Other duties and charges & $\begin{array}{l}\text { Prohibited on bound items } \\
\text { except if validly recorded } \\
\text { in Schedule }\end{array}$ & $\begin{array}{l}\text { Article II:1(b) of the GATT and } \\
\text { Understanding on Article II:1(b) }\end{array}$ \\
\hline $\begin{array}{l}\text { Internal charges collected } \\
\text { or enforced at time or } \\
\text { point of importation }\end{array}$ & $\begin{array}{l}\text { Permitted } \\
\text { provided the charge is } \\
\text { consistent with Article III: } 2\end{array}$ & Note to Article III of the GATT \\
\hline $\begin{array}{l}\text { Charges on importation } \\
\text { equivalent to internal taxes }\end{array}$ & $\begin{array}{l}\text { Permitted } \\
\text { provided the charge is } \\
\text { consistent with Article III: } 2\end{array}$ & Article II:2(a) of the GATT \\
\hline
\end{tabular}

imported products and may make the importation of products conditional upon the payment of charges equivalent to internal taxes on like domestic products.

The principles explained above are summarized in Table 1.

\section{The WTO law governing the application of domestic taxes and regulations to imported products and products destined for exportation}

Under the provisions of the GATT and the Subsidies Agreement on national treatment, export subsidies, and restrictions on the sale for export, ${ }^{2}$ a Member of the WTO may, in principle, apply to imported products the taxes and regulations it applies to domestic products and may exempt from its domestic taxes and regulations the products destined for export. The application of domestic taxes and regulations to imported products and products destined for export is optional: the Members have the right but not the obligation to impose the burdens borne by domestic products also on imported products. Equally, the Members may, but need not, apply to products sold abroad the measures applied to products sold domestically. As illustrated below and summarized in Table 2, a product exported from Member A to Member B could therefore be subject to four different forms of treatment:

- It could be exempted from domestic taxes or regulations by A upon exportation, and then taxed or regulated by B upon importation (taxation or regulation in the country of destination).

- It could be taxed or regulated by A and exempted from taxes or regulations by B (taxation or regulation at the country of origin).

2 See Articles II:2(a), III, including the Note to Article III, Note to Article XVI and XI:1 of the GATT and Note 1 to Article 1 and Annexes I-III of the Agreement on Subsidies and Countervailing Measures (SCM Agreement). 
- It could be taxed or regulated both by A and B (taxation or regulation in countries of origin and destination).

- It could be taxed or regulated by neither A nor B (taxation or regulation in neither country of origin nor country of destination).

Table 2. Possible treatment of products entering international trade

\begin{tabular}{|c|c|c|c|}
\hline & & \multicolumn{2}{|c|}{ Importing member ... } \\
\hline & & ... taxes/regulates & ... does not tax/regulate \\
\hline \multirow[t]{2}{*}{$\begin{array}{l}\text { Exporting } \\
\text { member } \ldots\end{array}$} & $\begin{array}{l}\ldots \text { does not } \\
\text { tax/regulate }\end{array}$ & $\begin{array}{l}\text { Taxation/regulation } \\
\text { at destination }\end{array}$ & $\begin{array}{l}\text { Tax/regulatory } \\
\text { exemption }\end{array}$ \\
\hline & ... taxes/regulates & $\begin{array}{l}\text { Double } \\
\text { taxation/regulation }\end{array}$ & $\begin{array}{l}\text { Taxation/regulation } \\
\text { at origin }\end{array}$ \\
\hline
\end{tabular}

The WTO's system of border adjustment accords WTO Members wide policy options regarding the treatment of products entering international trade. This can perhaps best be illustrated with the example of two countries that apply special environmental taxes or regulations to different chemical products that cause pollution either at the time of production or at the time of consumption, or both.

Take first a product that causes pollution at the time of consumption. In this case, the exporting Member may wish to refrain from imposing fiscal or regulatory burdens on products destined for exportation because the pollution does not take place within its territory. The importing Member, however, may wish to apply its environmental taxes or regulation not only to domestic but also imported products so as to discourage the consumption of the product. The two Members would then follow the destination principle. If a product causes pollution only at the time of production, the country of production might wish to tax or regulate both domestic and foreign sales, while the importing country would have no reason to impose a fiscal or regulatory burden on that product. In this case, the origin principle would prevail. If the product causes pollution both at the time of production and of consumption, both countries may wish to apply the environmental tax and hence subject it to double taxation. Conversely, if neither the production nor the consumption of the product causes pollution, neither the exporting nor the importing country would have any reason to apply the tax. The product would then be exempt by both countries from fiscal or regulatory burdens. WTO law thus permits Members to adopt fiscal and regulatory measures affecting each of the chemical products that take into account their different environmental impact.

The above principles on border adjustment apply only to domestic taxes and regulations imposed directly on products, such as a tax on the sale of a product or a regulation prescribing the physical characteristics of products sold in the domestic market. Domestic taxes and regulations that do not affect products as such, 
such as income taxes or a minimum-wage requirement, may not be offset through measures discriminating against products from other Members. Thus, WTO Members are, in principle, not permitted to impose fiscal burdens on products originating in countries with income taxes lower than their own ${ }^{3}$ or to prohibit imports from countries with a minimum wage lower than their own. ${ }^{4}$

For the reasons set out above, I cannot agree with a number of the statements of the commentators on border tax adjustments. The commentators' conclusion that 'efficient trade and domestic policies may only be achieved [under WTO law] if governments use taxes - rather than standards - to regulate negative domestic externalities' is incorrect because the basic principles of WTO governing the application of domestic taxes to imported products and those governing their application of domestic regulations are the same.

The commentators also fail to take into account in their analysis that the basic GATT provisions governing the application of internal taxes and regulations to imported products are limited to taxes imposed on products and regulations affecting products. Those provisions do not permit Members to offset the competitive impact of internal taxes borne by producers (such as energy taxes raising the cost of transportation) and regulations affecting exclusively production (such as emission regulations increasing the cost of production). The commentators' conclusion that governments could use border tax adjustments to offset the competitive impact of high energy taxes faced by domestic manufacturers is therefore incorrect.

While import charges serving this purpose could possibly be justified under the General Exceptions of Article XX of the GATT, in particular paragraph (g) on measures related to the conversation of exhaustible natural resources, there is no equivalent exception in the SCM Agreement that would permit the reimbursement of energy taxes borne by producers in respect of products destined for exportation. Unlike the WTO rules governing restrictive import measures, the WTO rules governing export subsidies thus do not exempt measures serving specific policy purposes. Thus, even a broad interpretation of Article XX permitting border adjustments designed to offset the competitive impact of high domestic energy taxes borne by domestic producers could resolve the problem identified by the commentators only in respect of imports but not exports.

The commentators state that the WTO system of border tax adjustments presents difficulties for federal states in which the sub-federal governments levy valueadded taxes (VAT) at different rates. If the federal government levies a charge on importation equivalent to the various VAT rates levied at the sub-federal level, a methodology would have to be developed to average them. This difficulty, so the commentators claim, could provide a new argument in favour of European tax harmonization.

3 This would be inconsistent with Article II:1(a) second sentence and/or Article I:1 of the GATT.

4 This would be inconsistent with Articles XI:1 and/or XIII:1 of the GATT. 
These statements are based on incorrect assumptions. Under the nationaltreatment provisions of Article III of the GATT, each sub-federal government may levy on the imported products the taxes it levies on domestic products. There is consequently no need to levy sub-federal taxes on imported products at the point of importation. Furthermore, if a Member of the WTO were to decide to levy a charge on importation equivalent to the VAT levied at the sub-federal level, the question of the calculation of an average of the various VAT rates would not arise. As pointed out by a GATT panel, 'the national treatment provisions require contracting parties to accord to imported products treatment no less favourable than that accorded to any like domestic product, whatever the domestic origin. Article III consequently requires treatment of imported products no less favourable than that accorded to the most-favoured domestic products'. ${ }^{5}$ If the imported and like domestic products may be sold in any of the sub-federal jurisdictions, which is normally the case, the charges on the imported product may thus not exceed the charges imposed on the domestic product sold in the sub-federal jurisdiction with the lowest VAT rate. If the charge on the imported product represented an average of the different VAT rates levied by all sub-federal governments, then imported products sold in the sub-federal jurisdictions with below-average VAT rates would be at a competitive disadvantage: domestic products would benefit from the below-average VAT rate in those jurisdictions while imported products sold in those jurisdictions would be subject to the average VAT rate. That would violate Article III:2 of the GATT. The complicated question of how to calculate an average VAT rate consequently does not arise under WTO law.

5 GATT Panel Report in United States - Measures Affecting Alcoholic and Malt Beverages, DS23/R, adopted on 19 June 1992, BISD 39S/206. 